\section{Impediments to Italian science}

SIR - Alison Abbott, writing about Italian academic promotion, has recently reported (Nature 366, 293; 1993) that a competition for professor in haematology (concorso) has been declared invalid by the court because the committee charged with selecting the winners "failed to distinguish the precise contribution made by candidates to collaborative papers whose authors also included a member of the committee". Abbott states that this is the first time a decision of a particular committee has been declared completely invalid in Italy.

However, in April 1993, the concorso for 24 professorships in paediatrics was declared invalid by the corte dei conti (court for administrative control) because the committee failed to apply the rules in selecting the winners. Both the haematology and the paediatric concorsi were denounced in Nature (353, 10; 1991 \& 356, $556 ; 1992)$ and in the Lancet $(2,1337$; 1992) because several of the losers had significantly better scientific credentials (based on indices of the impact of their publications) than the winners.

Thus the role played by the criticism of leading scientific journals cannot be underestimated, having been instrumental in changing the 'old' system. The discussions generated by concorsi have prompted the Italian Minister for Universities and Scientific Research to propose a change in the promotion system.

In this proposal, the committee will select a number of winners exceeding the number of available positions. Subsequently, each university with an opening will appoint a professor chosen from the winners. The idea is that the committees, being able to select more winners than before, will include candidates with the best scientific credentials in their list of winners. However, this may easily result in their exclusion from professorship. In fact, universities with openings will be left free to appoint anyone from the winners list. Thus, in some universities (described in a book by R. Simone, see Nature 366, $642 ; 1993)$, under the manipulating influ ence of local academic élites, it may happen that the best candidates, even if included among the winners, will not be appointed by any university and will lose their positions. The problem can be solved only by selecting and enforcing strict criteria for evaluating scientific credentials (publications in the international literature and their quality based on citation indexes), rather than leaving the committees free to establish criteria that may equate publication in local Italian journals without peer review with publication in leading international journals.

The core of the problem is that Italian universities lack mechanisms for promot- ing their scientific productivity and this is reflected in the lack of incentives to get the best professors. Thus universities may be happier to extend their favours to the local baroni and appoint a loyal pupil rather than selecting a brilliant scientist who may highlight the surrounding mediocrity. The traditional monopoly on power will be reinforced rather than challenged by the proposed changes. Members of the committees may now claim that they did not exclude the best candidates from the recommended appointment list.

While the Italian university system is succumbing to apoptosis, parliament, instead of introducing valid criteria for academic promotion, has just postponed the age of retirement of full professors from 70 to 72 years. Is this the new wave everybody is waiting for?

\section{Fernando Aluti}

Department of Allergy

and Clinical Immunology,

University of Rome 'La Sapienza', Italy

SIR - Italy's presence at the European Molecular Biology Laboratory (EMBL) is disproportionately small compared to its financial contribution and, understandably, Italians resent this situation. But we do not believe that EMBL is acting unfairly, nor that international organizations should necessarily count heads on the basis of nationality (see Nature 367, 205; 1994).

As Italian scientists who have worked abroad as well as in Italy, we should like to comment on the general situation of Italian scientists and job opportunities. In our opinion, the small numbers of Italian scientists in foreign countries cannot be explained without taking into account the Italian academic system.

The level of scientific education in Italy is lower than that of several other European countries. The Italian title 'Dottore' is given at the end of an undergraduate programme, the equivalent of a master's degree. Italian universities have recently introduced $\mathrm{PhD}$ programmes, but the relative lack of competitive research makes it difficult to train graduate students.

Italian students can be trained in foreign $\mathrm{PhD}$ programmes, and continue their training abroad. But, as previous correspondents have pointed out, a long stay abroad and the consequent better training are not recognized by the Italian academic system, which has close links with political interests. An "international" curriculum vitae is not better than an Italian one; it is simply different and does not fit the academic requirements of the Italian system.

Consequently, young scientists are discouraged from spending long periods abroad, as it is far more useful to nurture political friendship with appropriate members of committees that control the concorso. Ultimately, Italian scientists have to decide whether to remain in a foreign country or try to return home, where they can make little use of qualifications acquired abroad. This is why Italy experiences an otherwise inexplicable brain-drain, given the fact that it has the money, the culture and the people to build a serious scientific establishment. On the other hand, Italy has not developed a biotechnology industry, so there is virtually no job market for biologists and biochemists. This creates a further gap between Italy and its European partners.

In conclusion, it is not surprising that the Italian scientific community is not flourishing at EMBL. Italian scientists are poorly qualified to succeed in such an environment. Moreover, they do not feel it is important to stay abroad to learn new methods for their research, since in many cases such techniques will be impossible to reproduce in Italian laboratories. Nor do they feel compelled to publish good papers, for the reasons mentioned above.

Italy has an overwhelming responsibility for this disgraceful situation. The consequences of leaving EMBL for Italian science as well as for its public image will be very serious. We do not understand whether Italy is calling for an affirmative action employment policy by EMBL, or whether this is once more a confused, irrational government decision.

Italy seems to be blaming others for the results of its own corrupted politics. EMBL should not be blamed for the degradation of Italian science. We only hope that in the long run the changes in the Italian political system will eventually overcome these problems.

Renato Bruni

Rosario Leopard

Marjorie B. Kovler Viral Oncology

Laboratories,

University of Chicago,

Chicago, Illinois 60637, USA

\section{Warm brown fat}

SIR - The article by Lowell et al. (Nature 366, 740-742; 1993) deals with the genetic ablation of brown fat. For the ignorant, brown fat is what keeps us from freezing when the temperature dips below $0{ }^{\circ} \mathrm{C}$. This weekend in Montreal, we suffered $-31^{\circ} \mathrm{C}$. At least one of the authors of the Lowell et al. paper is a (misguided) Canadian. We take this opportunity to ask that she and her colleagues get their priorities straight. We need more brown fat not less. Jack A. Kornblatt

M. J. Kornblatt

Concordia University,

1455 de Maisonneuve Blvd W.

Montreal, Quebec H3G 1M8, Canada 